\title{
Public Sector Work and Happiness: an exploratory study
}

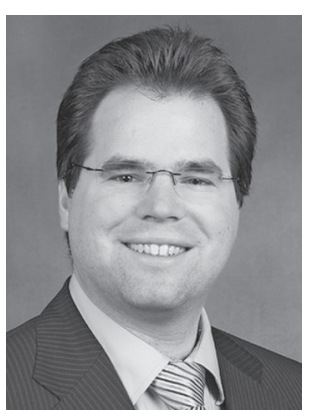

\author{
Fabian Homberg
}

Was sind die arbeitsrelevanten Bestimmungsfaktoren subjektiver Lebenszufriedenheit? Die Gluecksforschung hat hierzu eine Vielzabl von Erkenntnissen geliefert. Jedoch gibt es bisher nur wenig Befunde zur Frage, inwieweit sich diese Ergebnisse auf Arbeitsbedingungen im oeffentlichen Sektor nebertragen lassen und ob es diesbezueglich Unterschiede zwischen dem privaten und oeffentlichen Sektor gibt. Basierend auf den Erkenntnissen zweier Studien im oeffentlichen Sektor versucht dieser Beitrag erste Evidenz zu diesen Fragen zu generieren. Dabei liegt der Fokus auf Arbeitsbedingungen und HRM Praktiken. Im Ergebnis zeigen nur wenige Arbeitsbedingungen und Praktiken des oeffentlichen Sektors einen signifikanten Einfluss auf die Lebenszufriedenheit.

A large body of research has investigated the determinants of life satisfaction as one form of happiness. Whilst these studies have investigated both work and non-work related determinants of life satisfaction, they have not studied the impact of public sector employment on life satisfaction. Hence I investigate the impact of work-related characteristics and human resource management practices in different public sector organizations on the life satisfaction of public sector employees. The analyses presented in this paper draw on two different datasets with the aim to generate first insights into the relation between public sector employment and happiness. Results partially support that institutional differences between the private and public sector matter for employee happiness.

Glueck, Lebenszufriedenheit, oeffentlicher Sektor, Arbeitsbedingungen und-praktiken

Happiness, life satisfaction, public sector, work characteristics and practices

\section{Introduction}

Wellbeing and happiness at work are prominent issues on the political agenda, for researchers and corporate decision makers (Warr 2012). A large body of research has investigated the determinants of life satisfaction as one form of happiness (Frey, this issue; Frey \& Stutzer, 2005; 2012; Georgellis, Lange \& Tabvuma, 2012). Whilst these studies have investigated both work and non-work related determinants of life satisfaction, they have not studied the impact of public sector employment on life satisfaction beyond identifying that employees in the public sector have higher life satisfaction than their private sector counterparts (Clark, 1996). For example, whilst research has found that individual happiness returns back to a baseline level after major life events such as divorce, widowhood and disability there is very little understanding of the role organizations play in enhancing employee happiness. Work remains to be one of the most dissatisfying activities carried out each day (Knabe et al. 2010). 
Thus, studying happiness at work is an important topic for several reasons. First, the changing nature of work generates problems that may impact employee happiness negatively. This is particularly true for public sector work due to being constantly under reform pressure whereas it is by far unclear if the advocated reforms e.g. under a New Public Management agenda deliver their promises (e.g. see critical comments by Frey, Homberg, \& Osterloh 2013 and Siltala 2013). More specifically, (high performance) work-practices imported from the private sector lead to well-known problems: Issues such as cultures of excessive working hours (Kossek \& Lautsch 2008) and boundaryless careers (Arthur 2006) affect both mental and physical wellbeing of employees (Kossek 2012). Additionally, Erdogan et al. (2012) identify stronger needs to analyse workplace behaviours such as leadership styles of supervising personnel, employee perceptions of distributive justice and leader member exchange and their impact on employee happiness.

Second, another concern emerged in recent years over precarious employment relationships and economic studies of happiness have identified unemployment as the largest driver of unhappiness (Winkelmann 2014; Hetschko \& Schöb, this issue).

Third, institutional differences may play a role in generating happiness (Frey \& Stutzer 2002). A large literature in the field of public administration underscores the additional benefits of public sector work such as contributing to society (Ritz, Brewer \& Neumann 2018), and conducting 'meaningful' work (Tummers \& Knies 2013) which may affect the psychological states of well-being and happiness.

Nonetheless, happiness research has largely ignored public-private sector differences. Searching for the keyword "happiness" on the Web of Science and filtering results to the Public Administration category generates only 76 hits (as of $4^{\text {th }}$ July 2017); many of which are general economic policy related (compared to 376 in "Management" and 1459 in "Economics"). Thus, following, Luechinger, Meier and Stutzer (2010) who compared institutional differences between the private and public sector and assessed their effects on happiness measured as overall life satisfaction I exploit specifics of public sector organizations and sector differences to assess the various contributions different types of work behaviours and practices make to the happiness of employees.

To offer some answers to this question, I investigate the impact of work-related characteristics and Human Resource Management practices in different public sector organizations on the life satisfaction of public sector employees. The analyses presented in this paper draw on two different datasets with the aim to generate first insights into the relation between public sector employment and happiness. The paper remains exploratory in nature and the evidence presented should be considered as a building block to establish a research agenda on happiness in public sector working environments.

\section{Theory}

I draw on a series of arguments emerging from the human resources, public administration and personnel economics literature. First, the literature on work-life conflict argues that time demands from the work domain can result in lower well-being in the life domain (Allen, Herst, Bruck, \& Sutton, 2000; Greenhaus \& Beutell, 1985). Indeed, work-life conflict has been associated with lower life satisfaction, and deteriorating family relationships (Adams, King, and King; 1996).

Second, explanations based on work-life enrichment arguments stress the positive impact work can have on the life domain, as workplace events or experiences positively in- 
fluence well-being in the life domain. As Greenhaus and Powell (2006) argue, work and family experiences can have additive effects on an individual's overall well-being and it is likely that participation in both work and family life offers a buffer for the negative effects in either role. Other studies find that work-family enrichment leads to improvements in areas such as leadership abilities, psychological functioning, and multi-tasking, which in turn lead to increased life satisfaction (Carlson, Kacmer, Wayne, \& Grzywacz, 2006; Masuda, McNall, Allen, \& Nicklin, 2011).

Third, happiness has also been associated with employee outcomes that have significant benefits for firms such as lower levels of burnout (Harr \& Roche 2010), lower turnover intentions (Rode et al. 2007), higher levels of motivation (Hsieh 2010, Kossek et al., 2010) and increased job performance (Jones 2006). Lyubomirksy et al. (2005) showed that happier employees will be more open minded, creative and willing to take risks for the benefit of the organization. Zelenski et al. (2008) have shown that happiness in the form of positive affect is associated with higher productivity. Trust and workplace relations are also positively linked to happiness (Helliwell \& Huang 2011). According to Kossek et al. (2012) managers can steer workplace happiness through three levers: (i) control, (ii) social support and (iii) organizational culture.

Through utilization of specific human resource practices managers want to enforce the outcomes mentioned above (e.g. high employee performance). HR Practices are defined as a collection of activities (practices) that are used to manage the workforce. It takes a variety of different forms such as recruitment and selection, training and development, worker involvement, pay and rewards, flexibility (such as working from home, Hansen 2017, this issue), involvement in decision making, communications and employee welfare (Huselid 1995; Purcell 2003). For example, practices such as pay schemes, working conditions, job security, training opportunities, involvement, and team working have been associated with well-being on the job. In particular, open communication, team working, flexibility and work-life balance have been identified as drivers of organisational and personal wellbeing (Warr 2002; Dewe \& Cooper 2010).

Important to note in this context is the configuration of Human Resource Management practices: The effects on individuals rarely stem from one single practice in isolation but are rather driven by the composition of bundles of such practices (Gould-Williams, 2003). These practice bundles are most frequently assessed in relation to their contribution to employee and organizational performance (Huselid 1995), but very rarely their effects on happiness are studied. Nonetheless, it is important to focus on well-specified actions such as individual or bundles of HR practices in order to enhance employee happiness.

A fourth and final set of arguments relates to the nature of public sector organizations and public sector work itself. Due to their specific missions they have the power to attract individuals who are motivated by a desire to maximize social welfare (Boyne, 2002). This leads to the public sector having Human Resource Management practices, such as remuneration policies, working conditions, motivation measures, and work related attitudes which affect the relationship between work and life satisfaction in a different manner compared to other sectors. While under common New Public Management reforms the private sector work practice 'pay for performance' diffused widely into public sector organizations there are still differences in its implementation (Frey, Homberg and Osterloh 2013). For example, the mere fact that budgets in the public sector tend to be much smaller than those for international companies limits the incentive effect they are able to gener- 
ate. Similarly, recruitment and use of performance information differs significantly between sectors. Furthermore, the public sector has been shown to attract employees with higher levels of public service motivation than other sectors (Crewson, 1997; Asseburg \& Homberg 2017). Public service motivation is is "a particular form of altruism or pro-social motivation that is animated by specific dispositions and values arising from public institutions and missions" (Perry, Hondeghem, and Wise, 2010, p.682).

Higher levels of Public service motivation are associated with higher effort being exerted at work, for example public sector workers are found to donate more labour than private sector workers. Also, the pro-socially focused and located jobs in the public sector are associated with higher levels of PSM (Houston 2011). This implies the impact public sector work has on life satisfaction will differ depending on the type of public sector organization an individual works for. Human Resource Management practices will thus shape the impact of public sector work on life satisfaction.

In the following sections various pieces of evidence collected for different research projects over the past years are discussed. These data are a suitable basis for exploring the 'empirical hunch' (Bamberger \& Ang 2016) that institutional differences between the public and private sector are relevant for the generation of employee happiness.

\section{Study 1: The Police - a happy bunch of officers?}

A few years ago I was part of a team involved in a consulting project with a regional police force in Germany. At the time the organisation was in the process of establishing a new vision and overall strategy in order to become more aligned with the changing threats that were encountered (e.g. extremism, cybercrime). This gave us the opportunity to send a survey to 3000 randomly selected officers and staff members that also contained measures of job and life satisfaction.

The final sample of $\mathrm{N}=1165$ usable responses was representative for the total German police force in terms of gender and employment volume (i.e. full-time/part-time contracts), but public servants (as compared to privately employed employees ${ }^{1}$ ) were slightly overrepresented. For further sample details please refer to Homberg, Vogel and Weiherl (2017) and Masal and Vogel (2016) who use the same dataset.

Three constructs included in this survey are relevant for the purposes here. We measured happiness as overall life satisfaction using the question contained in the World Values Survey ${ }^{2}$ (All things considered, how satisfied are you with your life as a whole these days? $1=$ completely dissatisfied, $10=$ completely satisfied). Additionally, a global singleitem measure of job satisfaction was included $(1=$ completely dissatisfied, $10=$ completely satisfied). Finally, public sector organisations have a reputation of being overly bureaucratic. Thus, we included a measure of red tape, i.e. the extent of burdensome rules as perceived by the organisation's members (Bozeman and Feeny 2011) where higher values indicate higher levels of red tape.

Figure 1 displays the descriptive results of a comparison between red tape, job satisfaction and happiness. Panel A on the left hand side displays the perception of red tape bro-

1 The German public sector distinguishes between traditional civil servants, and individuals working in the public sector organisations under work contracts similar to the private sector. These are referred to as 'privately employed employees' "Angestellte im oeffentlichen Dienst").

2 German version: Wie zufrieden sind Sie in diesen Tagen und unter Berücksichtigung aller Umstände mit Ihrem Leben als Ganzem? (1 vollkommen unzufrieden -10 vollkommen zufrieden.). 
ken down to the different police directorates, branches, the headquarter and the police academy. It is noteworthy that members in all organisational units perceive extremely high levels of red tape (or bureaucracy in other words). Such values could point to a workforce that is highly dissatisfied and unhappy. However, in contrast, panel B on the right hand side of figure 1 exhibits fairly high levels of job satisfaction and happiness of the same members of the police. This is a counterintuitive finding which provides initial support for the argument that the public sector context matters for the build-up of employee happiness.

Figure 1. Comparison of Red tape, job satisfaction and happiness (Study 1)

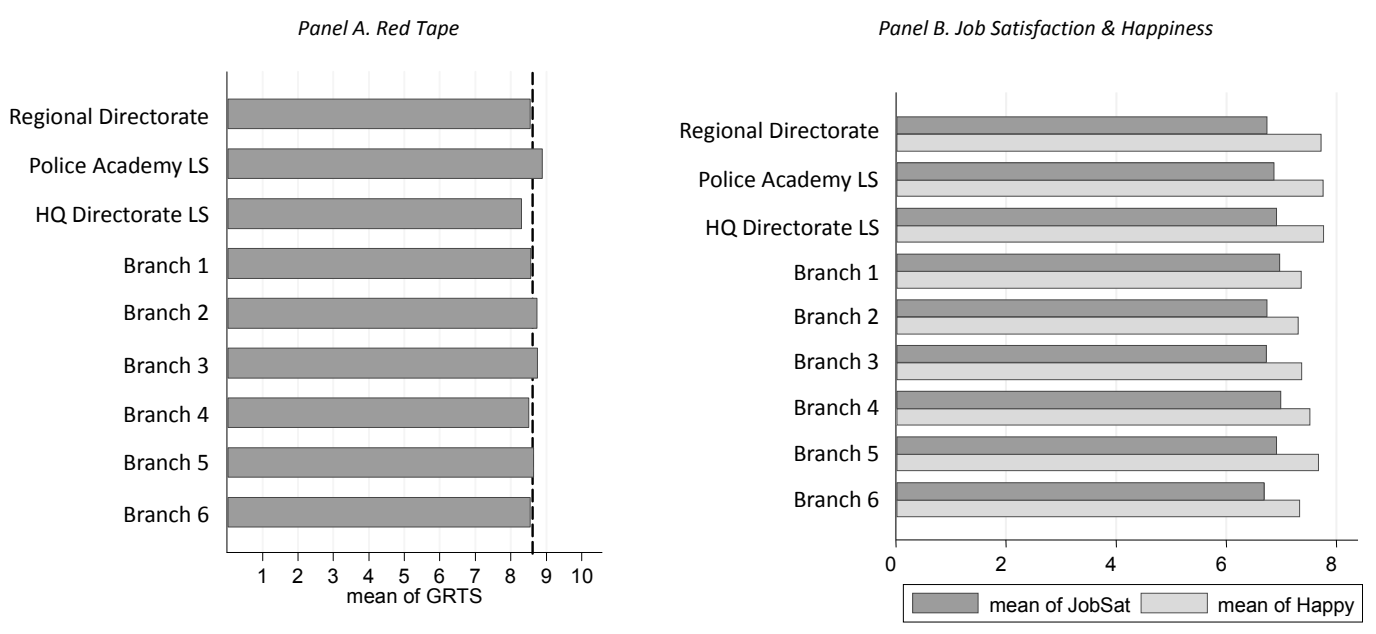

GRTS: Global Red Tape Scale; dashed line: sample mean

In a second step I regress happiness against a range of organisationally relevant variables, in particular different forms of leadership. The estimation strategy is as follows: Model 1 includes common demographic variables and model 2 adds relevant work characteristics such as the dummys for salary band, job type and career group. Ultimately, model 3 also includes the organisationally relevant behaviours and practices such as shared leadership (i.e. understood as a process in which group members lead each other; also sometimes referred to as distributed leadership) and transformational leadership (i.e. understood as charismatic leadership behaviours conveying inspirational motivation, intellectual stimulation combined with a concern for individual subordinates), access to resources and perceived organisational support. In all models we control for job satisfaction. Table 1 displays the results.

Considering the demographic variables, as expected marriage is associated with increased levels of happiness. In contrast to common findings in happiness research older employees are systematically less happy than their younger colleagues. More interesting, however, are the results relating to work behaviours and practices. First, closing the loop with the descriptive analyses above, the red tape variable is not significant indicating that perceptions of red tape have no impact on police officers' happiness levels. Second, access to resources exhibits a negative coefficient. This is surprising as access to resources has shown to positively affect self-perceptions of control and independence (Spreitzer 1996; 
Galperin 2012). Third, I turn attention to leadership keeping in mind that the police force is a traditional command-and-control organisation (Hattke, Vogel \& Znanewitz 2017). While shared leadership is associated with increased happiness levels, transformational leadership is not. The latter is striking given the importance that usually is attributed to transformational leadership with respect to - for example - creativity (Schmitt, Den Hartog \& Belschak 2016) and performance management (Pasha et al. 2017).

Table 1. Happiness of Police Officers (Study 1)

\begin{tabular}{|c|c|c|c|}
\hline & (1) & (2) & (5) \\
\hline VARIABLES & Happy & Happy & Happy \\
\hline \multirow[t]{2}{*}{ Female } & $0.132 *$ & 0.135 & 0.137 \\
\hline & $(0.0585)$ & $(0.107)$ & $(0.114)$ \\
\hline \multirow[t]{2}{*}{ Married } & $0.194 *$ & $0.335^{* * *}$ & $0.347 * *$ \\
\hline & $(0.0899)$ & $(0.120)$ & $(0.127)$ \\
\hline \multirow[t]{2}{*}{ Divorced } & -0.241 & -0.0563 & -0.0686 \\
\hline & $(0.133)$ & $(0.186)$ & $(0.182)$ \\
\hline \multirow[t]{2}{*}{ Widowed } & -1.088 & -0.929 & -0.964 \\
\hline & $(1.009)$ & $(0.991)$ & $(1.021)$ \\
\hline \multirow[t]{2}{*}{ Full time } & & 0.0120 & 0.0283 \\
\hline & & $(0.107)$ & $(0.111)$ \\
\hline \multirow[t]{2}{*}{ Officer } & & $25.33^{*}$ & 25.51 \\
\hline & & $(13.07)$ & $(14.83)$ \\
\hline \multirow[t]{2}{*}{ Admin } & & $25.17^{*}$ & 25.42 \\
\hline & & $(13.12)$ & $(14.87)$ \\
\hline \multicolumn{4}{|l|}{ Age: } \\
\hline \multirow[t]{2}{*}{ Up to 20} & & -0.141 & -0.0478 \\
\hline & & $(0.480)$ & $(0.531)$ \\
\hline \multirow[t]{2}{*}{21 to 30} & & 0.194 & 0.152 \\
\hline & & $(0.261)$ & $(0.267)$ \\
\hline \multirow[t]{2}{*}{41 to 50} & & -0.0719 & -0.0780 \\
\hline & & $(0.105)$ & $(0.0985)$ \\
\hline \multirow[t]{2}{*}{51 to 60} & & $-0.220^{*}$ & $-0.213^{*}$ \\
\hline & & $(0.113)$ & $(0.113)$ \\
\hline \multirow[t]{2}{*}{ Above 60} & & $-0.430 *$ & $-0.398^{*}$ \\
\hline & & $(0.216)$ & $(0.205)$ \\
\hline \multirow[t]{2}{*}{ Grade (A11 to A15) } & & 0.126 & 0.146 \\
\hline & & $(0.0791)$ & $(0.0882)$ \\
\hline
\end{tabular}


$\frac{\text { VARIABLES }}{\text { Salary Group }}$

Salary Group

POS

SHARED Lead.

Happy

$0.322 *$

(0.168)
Happy

0.326

(0.191)

$-0.143$

$0.130 * *$

0.0572

(0.0950)

$-0.0692 *$

$-0.0738$

$(0.0559)$

0.0123

(0.0410)

$0.390 * *$

(0.0390)

$4.309 \div \div$

1,165

0.199

Observations
Adjusted R-squared

Robust standard errors in parentheses $\because * \mathrm{p}<0.01, * \mathrm{p}<0.05, * \mathrm{p}<0.1$

The preceding analyses have given some insight into the relationship between happiness and work practices in one specific public sector organisation, namely a regional German Police force. However, the data did not allow for an analysis of differences between the public and private sector. In the next section, I present evidence from a second study that compares the two sectors with regards to happiness.

\section{Study 2: Public-Private Sector Comparison}

Study 2 relies on data from a convenience sample collected in early 2014. The sample consists of $\mathrm{N}=150$ respondents of which $44 \%$ work in the public sector. The majority of respondents are male $(57.3 \%)$ and between 21 and 30 years of age $(52 \%) .48 \%$ reported having received a university degree and $68.7 \%$ were in full-time employment. Respondents were German and American and the survey has been administered in both languages. Similar to study 1 the original focus of the survey was geared to a different topic (see Vogel et al. 2015 for details), but we were able to feed in the same happiness and job 
satisfaction measures. Those were collected alongside a number of work behaviours and practices.

\section{Measures}

Work Practices. Measures for use of performance information (UPI), and performance promotion management (PPM) were taken. UPI uses the four item scale from Moynihan, Pandey and Wright (2011) and has a reliability of 0.88. PPM is based on five items originally proposed by Liu, Liao and Loi (2012). Its reliability is 0.79 .

Work behaviours. The survey included perceptions of leadership behaviours. First, transformational leadership was measured based on Bass and Avolio (1999) and Felfe, Tartler and Liebmann (2004; alpha=0.88). Second, shared leadership uses the scale developed by Wood (2005). Please note that the shared leadership scale is a measure emphasizing general perceptions of teamwork. Its Cronbach's alpha is 0.80 .

Control variables. A number of standard control variables such as age, gender and education were included in the survey. We also controlled for perceived organisational support as this can significantly influence employee attitudes towards the organization.

\section{Results}

Again, I begin with a descriptive comparison of job satisfaction and happiness (see figure 2). Similar to the results in study 1 I also find in study 2 higher mean levels of job satisfaction and happiness present in the public sector (both measured on scales from 1 to 10 with high values on each scale indicating high levels of job satisfaction/happiness).

Figure 2. Comparison of Happiness and Job Satisfaction (Study 2)

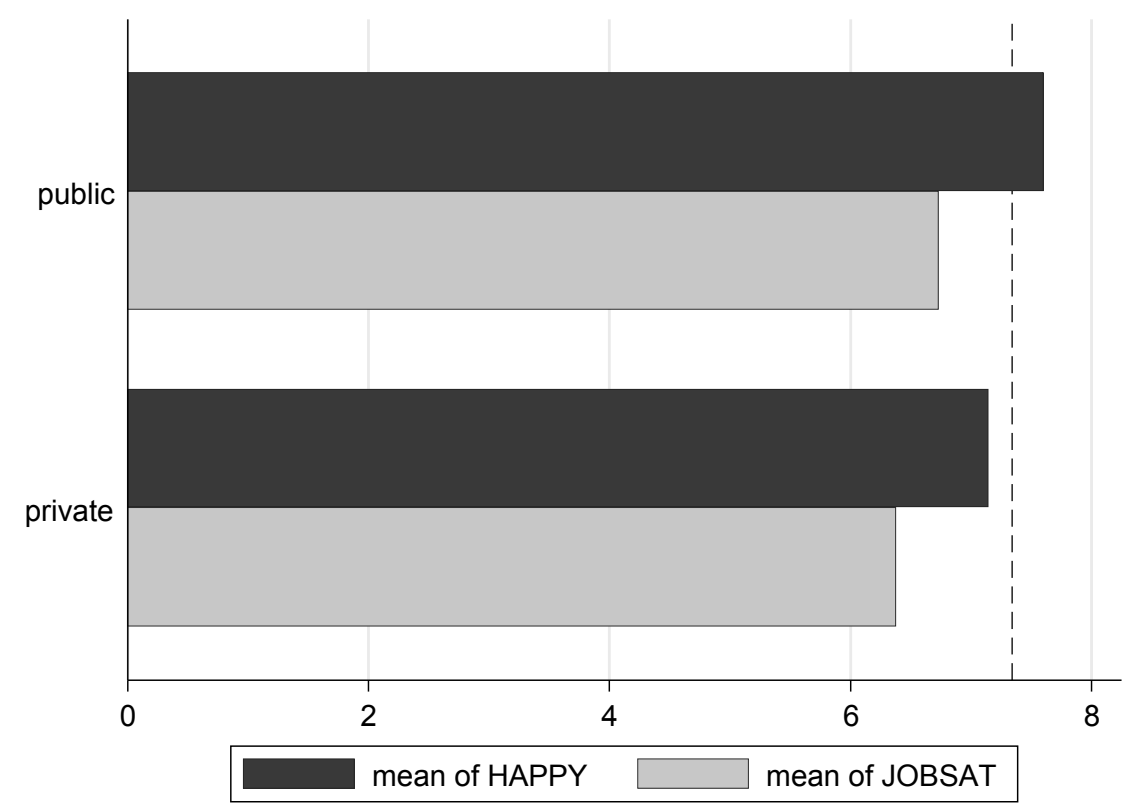

Note: dashed line is sample mean 
In a second step I regress happiness against a range of work behaviours. Model 1 displays results for the public sector, model 2 for the private sector and model 3 is the full sample. Table 2 displays the results. As demographic control, I only include the dummy for individuals of 40 years or more in the estimations. This is because happiness research shows that younger and older individuals tend to be happiest. However, those in the working population of 40 years and above may experience a dip in their happiness (Blanchflower \& Oswald 2008).

Surprisingly, the results do not show much difference between the two sectors. Perceived organizational support is a strong predictor of happiness in all specifications. Performance promotion motives display a weakly significant positive association with happiness in private sector organizations. All other variables remain insignificant.

Table 2. Happiness in Public-Private Comparison (Study 2)

\begin{tabular}{lccc}
\hline & $(1)$ & $(2)$ & $(3)$ \\
VARIABLES & HAPPY & HAPPY & HAPPY \\
\hline POS & $0.724^{* *}$ & $0.972^{* *}$ & $0.774^{* * *}$ \\
& $(0.339)$ & $(0.425)$ & $(0.270)$ \\
UPI & 0.0573 & 0.0967 & 0.0511 \\
& $(0.248)$ & $(0.260)$ & $(0.180)$ \\
PPM & -0.119 & $0.597^{*}$ & 0.299 \\
& $(0.250)$ & $(0.340)$ & $(0.226)$ \\
SHARED & 0.0192 & 0.149 & 0.157 \\
& $(0.245)$ & $(0.263)$ & $(0.184)$ \\
TFL & 0.238 & -0.178 & 0.0127 \\
& $(0.328)$ & $(0.280)$ & $(0.202)$ \\
AGE_40 & -0.852 & -0.0338 & -0.365 \\
& $(0.753)$ & $(0.546)$ & $(0.433)$ \\
Constant & $4.708^{* * *}$ & 1.584 & $3.040^{* * *}$ \\
& $(1.335)$ & $(1.671)$ & $(1.096)$ \\
Observations & 66 & 84 & 150 \\
Sample & Public & Private & Full \\
Adjusted R-squared & 0.109 & 0.096 & 0.106 \\
\hline
\end{tabular}

Robust standard errors in parentheses

$* * * \mathrm{p}<0.01, * \mathrm{p}<0.05, * \mathrm{p}<0.1$

POS: Perceived Organizational Support; UPI: Use of Performance Information; PPM: Performance Promotion Motives; SHARED: Shared leadership; TFL: Transformational Leadership; AGE_40: 1 if age $>=40$

\section{Discussion}

This study presented preliminary evidence on the associations between work behaviours and happiness in the public sector context. Overall, the evidence presented in the preceding sections only partially supports the assumption that the institutional context matters 
for the employees' happiness levels. Study 1 analysed a large dataset from a regional German police force. Starting off from the observation that high levels of happiness and job satisfaction are sustained in this organization notwithstanding extremely high levels of red tape, I investigated a number of work characteristics and behaviours. Access to resources was found to be negatively associated with happiness in the police data. The latter is an unexpected finding as resource access should facilitate work and therefore make the working day more endurable and happier. Surprisingly, the transformational leadership variable did not display any association with happiness whereas shared leadership did show a positive and significant association.

The difference between the two leadership constructs examined in study 1 may be explained by shared leadership's emphasis on aspects of teamwork. Perceived good relationships among team members enhance feelings of belongingness which should increase both motivation and happiness. In contrast, transformational leadership emphasizes that supervisors have visions for the future, are to some extent charismatic and excite their followers for their ideas. In the public sector context these aspects may be provided by the missions of the organizations and their ultimate goal to contribute to the public good as such. For example, Wright (2007) did show the influence of mission valence on public sector employee's motivation. For some individuals these elements may overcompensate the influence generated by transformational leaders. Similarly, the literature on substitutes for leadership (Kroon et al 2017, p.285) argues "that job, organization and worker characteristics may moderate the leader's ability to affect employee attitudes, behaviors, and performance" (see also Kerr \& Jermier 1978). Another possible explanation would focus on individual differences and self-selection. Are public sector employees, in particular police officers, more inclined to accept (legitimate) rules and authority than individuals choosing private sector jobs? I have no evidence on these questions, but they may thus provide interesting avenues for further investigation.

Study 2 then offered a comparison between public and private sector employees. However, it did not show pronounced differences between employees in the two sectors. Perceived organizational support was the only work characteristic showing a significant positive association with happiness. This result was consistent in all subsamples.

According to Warr's (2012, see also Warr and Clapperton 2010) discussion of happiness at work, there are nine elements needed to generate employee happiness. These include among others opportunities for personal influence, and a valued role. Perceived organizational support is likely to facilitate opportunities for personal influence in all organizations regardless of sector affiliation which might explain the results of study 2, i.e. the strong role perceived organizational support has throughout the sample. Benefitting from the support of the organization is likely to allow individuals to pursue their ideas for changing or improving work and thus facilitates personal influence. However, some job roles in the public sector may benefit from being valued to a larger extent from other people than private sector jobs. For example, the value citizens generally attribute to police officers and fire fighters tends to be higher than the value citizens attribute, for example, managers. Such value attribution from outsiders could be considered an institutionally embedded source of happiness creation.

Finally, the results presented here point to interesting future research questions. The descriptive results of both studies show fairly high levels of job satisfaction and happiness of public sector employees. This is particularly interesting in the police data where the major- 
ity of respondents pointed to high levels of red tape. Hence future research should put particular emphasis on coping processes, i.e. do public and private sector employees cope differently with day-to-day organizational intricacies? Coping strategies might be shaped by socialization processes, organizational processes and cultures. According to conservation of resources theory (Hobfoll 2001; for a critical review see Halbesleben et al. 2014) individuals who cope better do suffer less from (psychological) resource depletion (e.g. due to stress or other workplace demands) and thus are likely to be happier because they hold more personally valued resources.

Another avenue for future research arises from the nature of public service work. Two aspects need to be considered. First, a majority of public sector jobs are indeed service related roles, many of them characterized by frequent contacts with citizen potentially leading to emotional exhaustion. In such contexts happiness levels may be influenced by the individuals' ability to manage their own emotions (Bhave \& Glomb 2016) as suppressing them may negatively impact on happiness. Second, ideas of relational job design (Grant 2007; Taylor 2014) appear to be particularly suitable for being analysed in a public sector context and their ability to influence happiness levels. As Dewe and Cooper (2010, p.103) state "when the different work features are considered it is also important to continue to explore (...) whether different features produce different forms of happiness (...)".

Finally, it would be worthwhile to link key debates in the public management literature to happiness research. For example, it is intuitively appealing to assume red tape has a negative impact on happiness but there is little empirical evidence to support this assumption. Also, research showed that happiness is linked to traits (understood as enduring individual level dispositions, e.g. see Tkach and Lyubomirski 2006). As Tkach and Lyubomirksy (2006) summarize: "In contrast to demographic and circumstantial variables, personality traits account for a large portion of the variance in individual differences in happiness - as much as 40-50\% (Diener et al., 1999) - and appear to be critical to well-being." Thus, if happiness is affected by individual level dispositions it is worthwhile to investigate the relation of trait-like individual differences (e.g. public service motivation) and happiness. Ultimately, different administrative systems may impact citizen happiness and thus constitutes a fruitful area of investigation.

\section{Limitations}

The results presented in the preceding sections need to be considered bearing some limitations in mind. First, while study 1 draws on a relatively large dataset it is focused on one single public sector organization which is not representative of common public service office jobs. The effects of public sector employment on employee happiness are likely going to vary depending on the type of organization and job an individual has in the public sector. However, the insights generated by studying police officers reflect the essence of public service jobs in terms of contribution to society. Second, study 2 relies on a relatively small convenience sample. Nonetheless, it allows for a first glimpse at happiness comparing both the private and public sector. Finally, both study 1 and study 2 are based on crosssectional data limiting the ability to draw causal inferences. Hence, all results should be considered as associations without making causal claims. 


\section{Conclusion}

Research on happiness in the public sector is scarce. Using two studies I tried to follow-up on the argument that institutional differences between the private and public sector matter for employee happiness. While results partially support this idea, more research on happiness in public sector contexts is needed.

\section{References}

Adams, G. A., King, L. A., \& King, D. W. (1996). Relationships of job and family involvement, family social support, and work-family conflict with job and life satisfaction. Journal of Applied Psychology, 81(4), 411.

Allen, T. D., Herst, D. E. L., Bruck, C. S., \& Sutton, M. (2000). Consequences associated with work-to-family conflict: A review and agenda for further research. Journal of Occupational Health Psychology, 5(2), 278-308.

Asseburg, J., \& Homberg, F. (2017). Public Service Motivation or sector rewards? Two studies on the determinants of sector attraction. Working Paper presented at the Academy of Management Annual Meeting, 2017, Atlanta.

Arthur, M. (2006). The boundaryless career: a new perspective for organizational inquiry. Journal of Organizational Behavior, 15(4), 295-306.

Bamberger, P., \& Ang, S. (2016). The quantitative discovery: What is it and how to get it published. Academy of Management Discoveries, 2(1), 1-6.

Bhave, D. P., \& Glomb, T. M. (2016). The role of occupational emotional labor requirements on the surface acting-job satisfaction relationship. Journal of Management, 42(3), 722-741.

Blanchflower,D.G. \& Oswald, A.G. (2008). Is well-being U-shaped over the life cycle? Social Science \& Medicine, 66(8), 1733-1749.

Boyne, G. A. (2002). Public and private management: what's the difference? Journal of Management Studies, 39(1), 97-122.

Bozeman, B., \& Su, X. (2015). Public service motivation concepts and theory: A critique. Public Administration Review, 75(5), 700-710.

Avolio, B. J., \& Bass, B. M. (1999). Re-examining the components of transformational and transactional leadership using the Multifactor Leadership Questionnaire. Journal of Occupational and Organizational Psychology, 72, 441-462.

Carlson, D. S., Kacmer, K. M., Wayne, J. H., \& Grzywacz, J. G. (2006). Measuring the positive side of the work-family interface: Development and validation of a work-family enrichment scale. Journal of Vocational Behavior, 68(1), 131-164.

Clark, A. E. (1996). Job satisfaction in Britain. British Journal of Industrial Relations, 34(2), 189-217.

Crewson, P. E. (1997). Public-service motivation: Building empirical evidence of incidence and effect. Journal of Public Administration Research and Theory, 7(4), 499-518.

Dewe, P., \& Cooper, C. (2012). Well-being and work: Towards a balanced agenda. Springer.

Erdogan, B., Bauer, T., Truxillo, D., \& Mansfield, L. (2012). Whistle While You Work: A Review of the Life Satisfaction Literature. Journal of Management, 38(4), 1038-1083.

Felfe, J., Tartler, K., \& Liepmann, D. (2004). Advanced research in the field of transformational leadership. Zeitschrift für Personalforschung, 18, 1-27. 
Frey, B.S. (2017). Research on Well-Being: Determinants, Effects, and its Relevance for Management. Die Unternehmung, this issue.

Frey, B.S., Homberg, F. \& Osterloh, M., 2013. Organizational Control Systems and Pay-for-Performance in the Public Service. Organization Studies, 34 (7), 949-972.

Frey, Bruno S. \& Alois Stutzer (2002). Happiness and Economics: How the Economy and Institutions Affect Well-Being. Princeton and Oxford: Princeton University Press.

Frey, Bruno S. \& Alois Stutzer (2005). Happiness Research: State and Prospects. Review of Social Economy, 62 (2), 207-228.

Frey, Bruno S. \& Alois Stutzer (2012). The Use of Happiness Research for Public Policy. Social Choice and Welfare, 38 (4), 659-674.

Galperin, B. L. (2012). Exploring the nomological network of workplace deviance: Develop-ing and validating a measure of constructive deviance. Journal of Applied Social Psy-chology, 42, 2988-3025.

Georgellis, Y., Lange, T., \& Tabvuma, V. (2012). The impact of life events on job satisfaction. Journal of Vocational Behavior, 80(2), 464-473.

Gould-Williams, J. (2003). The importance of HR practices and workplace trust in achieving superior performance: A study of public-sector organizations. International Journal of Human Resource Management, 14 (1), 28-54.

Grant, A. M. (2007). Relational job design and the motivation to make a prosocial difference. Academy of Management Review, 32(2), 393-417.

Greenhaus, J. H., \& Beutell, N. (1985). Sources of conflict between work and family roles. Academy of Management Review, 10(1), 76-88.

Greenhaus, J. H., \& Powell, G. N. (2006). When work and family are allies: A theory of work-family enrichment. Academy of Management Review, 31(1), 72-92.

Haar, J. M., \& Roche, M. A. (2010). Family supportive organization perceptions and employee outcomes: The mediating effects of life satisfaction. The International Journal of Human Resource Management, 21(7), 999-1014.

Hattke, F., Vogel, R. \& Znanewitz, J. (2017): Satisfied with Red Tape? Leadership, Civic Duty, and Career Intention in the Military. Public Management Review, forthcoming.

Hansen, K.F. (2017). Home Office -Salutary Action on Combining Work and Family?, Die Unternehmung, this issue.

Helliwell,J.F.,\& Huang,H. (2011). Well-being and Trust in the Workplace. Journal of Happiness Studies, 12(5),747-767.

Hetschko, C. \& Schöb, R. (2017). Modes of Employment and Identity. Die Unternehmung, this issue.

Hobfoll, S. E., \& Shirom, A. (2001). Conservation of resources theory: Applications to stress and management in the workplace.

Homberg, F., Vogel, R. \& Weiherl, J. (2017). 'Public service motivation and continuous organizational change. Taking charge behaviour at police services.' Public Administration, forthcoming.

Houston, D. J. (2011). Implications of occupational locus and focus for public service motivation: Attitudes toward work motives across nations. Public Administration Review, 71(5), 761-771.

Hsieh, T. (2010). Delivering happiness: A path to profits, passion, and purpose. New York: Business Plus.

Huselid, M. A. (1995). The impact of human resource management practices on turnover, productivity, and corporate financial performance. Academy of Management Journal, 38(3), 635-672. 
Jones, M. D. (2006). Which is a better predictor of job performance: Job satisfaction or life satisfaction. Journal of Behavioral and Applied Management, 8(1), 20-42.

Kerr, S., \& Jermier, J. M. (1978). Substitutes for leadership: Their meaning and measurement. Organizational behavior and human performance, 22(3), 375-403.

Knabe, A., Rätzel, S., Schöb, R., \& Weimann, J. (2010). Dissatisfied with Life but Having a Good Day: Time-use and Well-being of the Unemployed. The Economic Journal, 120(547), 867-889.

Kossek, E., Kalliath, T., \& Kalliath, P. (2012). Achieving employee wellbeing in a changing work environment. An expert commentary on current scholarship. International Journal of Manpower, 33(7), 738-753.

Kossek, E.E., Lewis, S., \& Hammer, L.B. (2010). Work-life initiatives and organizational change: Overcoming mixed messages to move from the margin to the mainstream. Human Relations, 2010 63(1), 3-19.

Kossek, E. and Lautsch, B. (2008), CEO of Me: Creating a Life ThatWorks in the Flexible Job Age, Wharton School Publishing, Pearson.

Lyubomirsky, S., King, L., \& Diener, E. (2005). The benefits of frequent positive affect: does happiness lead to success?. Psychological bulletin, 131(6), 803.

Masal, D. \& Vogel, R. (2016). 'Leadership, use of performance information and job satisfaction: Evidence from police services.' International Public Management Journal, 19(2): 208-234.

Masuda, A. D., McNall, L. A., Allen, T. D., \& Nicklin, J. M. (2012). Examining the constructs of work-to-family enrichment and positive spillover. Journal of Vocational Behavior, 80(1), 197-210.

Kroon, B., Kroon, B., van Woerkom, M., van Woerkom, M., Menting, C., \& Menting, C. (2017). Mindfulness as substitute for transformational leadership. Journal of Managerial Psychology, 32(4), 284-297.

Liu, D., Liao, H., \& Loi, R. (2012). The dark side of leadership: A three-level investigation of the cascading effect of abusive supervision on employee creativity. Academy of Management Journal, 55(5), 1187-1212.

Luechinger, S., Meier, S., \& Stutzer, A. (2010). Why does unemployment hurt the employed? Evidence from the life satisfaction gap between the public and the private sector. Journal of Human Resources, 45(4), 998-1045.

Pasha, O., Poister, T.H., Wright, B.E., \& Thomas, J.C. (2017). Transformational Leadership and Mission Valence of Employees: The Varying Effects by Organizational Level. Public Performance \& Management Review, 40(4), 722-740

Purcell, J. (2003). Understanding the people and performance link: unlocking the black box. CIPD Publishing.

Rode, J. C., Rehg, M. T., Near, J. P., \& Underhill, J. R. (2007). The effect of work/family conflict on intention to quit: The mediating roles of job and life satisfaction. Applied Research in Quality of Life, 2(2), 65-82.

Schmitt, A., Den Hartog, D. N. and Belschak, F. D. (2016), Transformational leadership and proactive work behaviour: A moderated mediation model including work engagement and job strain. Journal of Occupational and Organizational Psychology, 89(3), 588-610.

Siltala, J. (2013). New Public Management: The evidence-based worst practice?. Administration \& Society, 45(4), 468-493.

Spreitzer, G. M. (1996). Social structural characteristics of psychological empowerment. Academy of Management Journal, 39, 483-504. 
Taylor, J. (2014). Public service motivation, relational job design, and job satisfaction in local government. Public Administration, 92(4), 902-918.

Tkach, C., \& Lyubomirsky, S. (2006). How do people pursue happiness?: Relating personality, happiness-increasing strategies, and well-being. Journal of Happiness Studies, 7(2), 183-225.

Tummers, L. G., \& Knies, E. (2013). Leadership and meaningful work in the public sector. Public Administration Review, 73(6), 859-868.

Warr, P. (2012). Work, happiness, and unhappiness. New York, NY: Psychology Press.

Warr, P. (2002). The study of well-being, behaviour and attitudes. In P. Warr (Ed.). Psychology at work. London: Penguin Books, pp. 1-25

Warr, P., \& Clapperton, G. (2010). The joy of work?: Jobs, happiness, and you. Routledge.

Wood, S.W. (2005). Determinants of shared leadership in management teams. International Journal of Leadership Studies, 1(1): 64-85

Winkelmann, R. (2014). Unemployment and happiness. IZA World of Labor.

Wright, B. E. (2007). Public service and motivation: Does mission matter?. Public administration review, 67(1), 54-64.

Zelenski, J. M., Murphy, S. A., \& Jenkins, D. A. (2008). The happy-productive worker thesis revisited. Journal of Happiness Studies, 9(4), 521-537.

Fabian Homberg, Associate Professor HRM \&OB, University of Southampton

Anschrift: Southampton Business School, Highfield, SO17 1BJ, Southampton, UK, Email:f.homberg@soton.ac.uk 